\title{
A STUDY OF HANFORD CAPABILITY FOR SOLAR ENERGY RESEARCH AND DEVELOPMENT
}

K. Drumheller

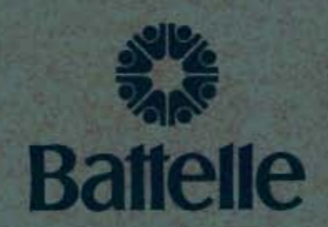

Pacific Northwest Laboratories

Richland, Washington 99352

NOVEMBER 1973

Prepared for the U.S. Atomic Energy

Commission under Contract AT(45-1):1830 
The report was prepared as an account of work sponsored by the United States Government. Neither the United States nor the United States Atomic Energy Commission, nor any of their employees. nor any of their contractors, subcontractors, or their employees, makes any warranty, express or implied, or assumes any legal liability or responsibility for the accuracy, completeness or usefulness of any information. apparatus, product or process disclosed, or represents that its use would not infringe privately owned rights

\author{
PACIFIC NORTHWEST LABORATORY \\ operated by \\ BATTELLE \\ for the \\ U.S. ATOMIC ENERGY COMMISSION \\ Under Contract AT(45-1)-1830
}

\author{
Printed in the United States of Americ \\ Available from \\ National Technical Information Service \\ U.S. Department of Commerce \\ 5285 Port Royal Road \\ Springfield, Virginia 22151
}

Price: Printed Copy 55.45; - Microfiche \$1.45 
A STUDY OF HANFORD CAPABILITY

FOR SOLAR ENERGY RESEARCH

AND DEVELOPMENT

by

K. Drumheller

\author{
Prepared for \\ Richland Operations Office \\ U.S. Atomic Energy Commission
}

November 1973

\title{
BATTELLE
}

PACIFIC NORTHWEST LABORATORIES

RICHLAND, WASHINGTON 99352 


\section{EXECUTIVE SUMMARY}

There is a rapidly growing interest in solar energy. Several studies indicate that solar energy can provide a substantial portion of U.S. energy requirements by 1990-2000.

The Hanford site provides unique capability for solar energy R\&D work. The basic attributes of the Hanford site which could make it one of the world's leading solar energy sites are:

\section{Site Attributes}

Large available land areas

Consistent sunshine during much of the year (although not comparable to Arizona and the U.S. Southwest)

Extreme temperatures for test purposes $\left(-27^{\circ}\right.$ to $\left.115^{\circ} \mathrm{F}\right)$

Cooling water availability

Ecology approximating ecology in some other solar areas

Facilities Attributes

R\&D facilities applicable to most solar technology

Equipment immediately useful for solar energy programs

\section{Personnel Attributes}

Technical background in most areas of solar energy technology

Experience with large energy systems

Background in systems analysis

From the solar energy production standpoint, the energy which falls on the 600+ square miles fenced off within the Hanford site would produce approximately 100,000 megawatts if a 33-1/38 efficiency can be achieved. In terms of input to the nation's energy requirements, if a $90 \%$ efficient 
process for the production of hydrogen from water can be achieved, the Hanford site could produce 8.2 quadrillion btu per year, or $7 \%$ of the nation's 1985 forecast energy requirements.

Preparation of a national solar energy $R \& D$ program outline and a comparison of Hanford capability with this outline show that Hanford can contribute in almost every area.

There are several programs which could be undertaken immediately to begin to take advantage of the Hanford site. These include:

1. Process development for photovoltaic device fabrication.

2. Process development for thin film heat trap fabrication.

3. Laboratories for collecting, analyzing and disseminating solar insolation data and for device testing and calibration.

4. Utilization of 100 Area emergency generators for power production.

5. Hydrogen production development.

6. Building heating and cooling system development.

7. Systems analysis and economics.

8. System design.

9. National program planning. 
TABLE OF CONTENTS

Page

1.0 Introduction . . . . . . . . . . . . . . . 1

2.0 Hanford Capability . . . . . . . . . . . . 3

2.1 General . . . . . . . . . . . . . 3

2.2 Site Attributes . . . . . . . . . . . . . . 3

2.3 Personnel and Facilities Attributes . . . . . 4

3.0 Hanford Site Information . . . . . . . . . . 7

3.1 General ................... . . 7

3.2 Climatology . . . . . . . . . . . . . 8

4.0 Immediate Program Possibilities . . . . . . . 18

4.1 Process Development for Photovoltaic

Device Fabrication . . . . . . . . . . 18

4.2 Process Development for Thin Film

Heat Trap Fabrication . . . . . . . . . 19

4.3 Laboratories for Collecting, Analyzing and Disseminating Solar Insolation Data, and for Device Testing and Calibration . . 20

4.4 Utilization of 100 Area Emergency

Generators for Power Production . . . . . . 20

4.5 Hydrogen Production Development . . . . . . 21

4.6 Building Heating and Cooling

System Development . . . . . . . . . . . 23

4.7 Systems Analysis and Economics . . . . . . 23

4.8 System Design . . . . . . . . . . . . . 23

4.9 National Program Planning . . . . . . . . 23

4.10 other .................. . 24

5.0 Solar Energy Sponsors . . . . . . . . . . 25

5.1 Government . . . . . . . . . . . . . 25

5.2 Industrial sponsors ............ . 26

REFERENCES . . . . . . . . . . . . . . . . . 27

Appendix A. Solar Energy Background

Appendix B. Program Possibilities

Appendix C. FY 1973 Solar Energy Programs

Sponsored by NSF 
List of Figures

Page

Figure 1. Mean Daily Solar Radiation

(Langleys), July . • . . . . . 9

Figure 2. Mean Daily Solar Radiation

(Langleys), Annual. . . . . . 11

Figure 3. Mean Total Hours of Sunshine,

Annual .. . . . . . . . . 14

Figure 4. Mean Monthly Total Hours of

Sunshine, July . . . . . . . 16

Figure 5. Illustration of the Difference in

Solar Energy on Horizontal and

Tilted Collectors . . . . . . 17

$$
\text { List of Tables }
$$

Table 1. Solar Energy Program Outline • • 5

Table 2. Mean Daily Solar Radiation

(Langleys) and Years of Record

Used . . . . . . . . . . • 12

Table 3. Mean Number of Hours of

Sunshine . . . . . . . . . 15 


\subsection{INTRODUCT ION}

An investigation of the Hanford site as a possible location for solar energy research and development work was conducted. The conclusion was that a great contribution can be made to the nation's energy programs through utilization of Hanford land, facilities and people on solar energy R\&D. The site also has great potential as a solar energy production site, particularly if solar energy hydrogen production systems are developed.

Areas discussed herein include the climate characteristics of the Hanford reservation, the facilities available, and the personnel available. Some immediate program possibilities are also discussed.

There is increasing U.S. and world interest in the development of new sources of energy. Solar energy is one of the most promising sources which is relatively untapped today .

In recent years the potential for the utilization of solar energy has increased greatly. An outline for a national solar energy R\&D program was recently issued by a National Academy of Sciences panel. (1) The panel study was conducted by NASA and NSF. The recommendation was for a program of $R \& D$ estimated to cost $\$ 3.5$ billion over the next 15 years. The program would include the application of solar energy to building heating and cooling, the production of renewable new clean fuel sources by photosynthesis of organic materials and hydrogen, and electrical power generation by solar thermal conversion. Also included are direct solar energy conversion, wind energy conversion and power from ocean thermal differences. The national outline dwells very briefly on hydrogen production. Recent developments have improved the potential for hydrogen production from solar energy. 
The magnitude of solar energy is indicated in the following statements.

- The solar energy intercepted by the earth is $1.76 \times 10^{11}$ megawatts.

- In the U.S., the average incidence of solar energy on the ground is 17 thermal watts/ft. ${ }^{2},(1)$ or $17 \times\left(5.3 \times 10^{3}\right)^{2}=474$ megawatts per square mile. This average considers day and night, cloudy and sunny days, and seasonal variation.

- On a sunny summer day at Hanford, the peak power approaches 3000 megawatts thermal per square mile. The yearly average in the Richland area is about equal to the national average.

- With a $10 \%$ conversion efficiency, 1970 U.S. electrical energy requirements could have been supplied by the solar energy incident on less than $0.2 \%$ of the U.S. land area. (1)

- The energy which falls on the roof area of the average house is enough to supply all of its electrical needs and all of its heating and cooling.

- From U.S. land area alone, it is not unreasonable to consider all U.S. power needs being supplied by solar power in the next century or two. Use of ocean space and orbiting solar power collectors could increase the available power immensely.

For those not familiar with solar energy systems, a brief discussion of several systems being considered today will be found in Appendix A. 


\subsection{HANFORD CAPABILITY}

\subsection{General}

From the experience of Hanford contractors (and other organizations), a background in nuclear energy is applicable in many ways to the development of other energy sources. Hanford facilities and personnel have in recent years been active, and in several cases highly successful, in the development of geothermal and fossil energy systems in addition to nuclear.

A comparison of the technological developments required for a wider utilization of solar energy with Hanford capability illustrates a unique correlation. Hanford can contribute in almost all of the technological areas.

\subsection{Site Attributes}

The basic attributes of the Hanford site which could make it one of the world's leading solar energy sites are:

Large available land areas

Consistent sunshine during much of the year (although not comparable to Arizona and the US southwest)

Extreme temperatures for test purposes $\left(-27^{\circ} \mathrm{F}\right.$ to $\left.115^{\circ} \mathrm{F}\right)$

cooling water availability

Ecology approximating ecology in some other solar areas

From the solar energy production standpoint, the energy which falls on the 600+ square miles fenced off within the Hanford site would produce approximately 100,000 megawatts if a 33-1/38 efficiency can be achieved. In terms of input to the nation's energy requirements, if a $90 \%$ efficient process for the production of hydrogen from water can be achieved, the Hanford site could produce 8.2 quadrillion btu per year, or $7 \%$ of the nation's 1985 forecast energy requirements.

Specific Hanford site information is discussed in section 3.0 below. 
2.3 Personnel and Facilities Attributes

Personnel attributes include:

Technical background in most areas of solar energy technology

Experience with large energy systems

Background in systems analysis

Facilities attributes include:

R\&D facilities applicable to most solar technology

Equipment immediately useful for solar energy programs

Table $l$ is an outline of a national solar energy program. This outline is based on the NASA-NSF study (1) with some additions. The areas in which Hanford could readily make a significant contribution in terms of facilities or personnel are indicated in Table 1 . It is significant to note that Hanford could contribute in almost every area. The degree of expertise varies. However, in many areas, such as thin film work, materials compatibility, photometric calibration, equipment development, and economics, Hanford personnel and facilities are among the world leaders. Specific examples of immediate program possibilities are discussed in section 4.0, page 17 . A more detailed discussion of possible programs will be found in Appendix B . 
Table 1

SOLAR ENERGY PROGRAM OUTL INE

Areas in Which Hanford Can Contribute

Personnel Facilities

1.0 GENERAL

1.1 Solar Energy Availability

1.2 Albedo

1.3 Solar Energy Characteristics

1.4 Photon--Matter Interactions

1.5 Environmental Effects

1.6 Economics

1.6.1 Overa 11 Energy System

1.6.2 Individual Systems

1.6.3 Technical Assistance

1.7 Systems Analysis

$\begin{array}{ll}X & X \\ X & X \\ X & X \\ X & X \\ X & X \\ X & X \\ X & X \\ X & X \\ X & X \\ X & X\end{array}$

2.0 THERMAL CONVERSION

2.1 Collectors

2.1.1 Reflector Materials \& Fab

2.1.2 Corrosion Resistant Materials

2.1.3 Compatibility

2.1.4 Fresnel Lenses

2.1.5 Thin Film Heat Traps

2.1.6 Mass Production Techniques

2.2 Storage

2.2.1 Eutectic Salts

2.2.2 Geothermal Caverns

2.2.3 Other

2.3 Heat Transfer

2.4 Sys tems

2.5 Pilot Plant

2.6 Demonstration Plant

$\begin{array}{ll}x & x \\ x & x \\ x & x \\ x & x \\ x & x \\ x & x \\ & x \\ x & x \\ x & x \\ x & x \\ x & x \\ x & x \\ x & \end{array}$

\subsection{DIRECT CONVERSION}

3.1 Solid State Studies

3.1.1 General

3.1.2 Silicon Systems

3.1.3 CdS Systems

3.1.4 Other Inorganic

3.1.5 Organic

3.2 Solar Cell Fabrication

3.2.1 Single Crystal

3.2.2 Polycrystalline

3.2.3 Amorphous

3.2.4 Organics

$\begin{array}{ll}X & X \\ X & X \\ X & X \\ X & X \\ - & - \\ X & X \\ X & X \\ X & X \\ - & -\end{array}$


TabTe 1 (Cont'd)

Areas in Which Hanford

Can Contribute

Personnel Facilities

3.0 DIRECT CONVERSION (Cont'd)

3.3 Power Collection

3.4 Controls

3.5 Pilot Plant

3.6 Demonstration Plant

$x \quad x$

$x \quad x$

$\begin{array}{ll}x & x \\ x & x\end{array}$

$x \quad x$

4.0 CHEMICAL CONVERSION

4. 1 Thermal Dissociation of $\mathrm{H}_{2} \mathrm{O}$

4.2 Hi Temperature Electrolysis

4.3 Combined Thermal-Electrolysis

4.4 Other Chemical Conversion Sys tems

4.5 Chemical Energy Storage

4.6 Support

$\begin{array}{ll}x & X \\ X & X \\ X & X \\ X & X \\ X & X \\ X & X\end{array}$

5.0 PHOTOSYNTHESIS

5.1 Growing Forests

5.2 Other Photosynthes is

5.3 Conversion of Organic Materials to Fuels or Heat

$\begin{array}{ll}x & X \\ X & X \\ X & X\end{array}$

6.0 BIO-CONVERSION

6.1 Photosynthesis Bio-conversion

6.2 Thermal Bio-conversion

6.2.1 Algae

6.2.2 Organics

$\begin{array}{ll}x & x \\ x & x\end{array}$

$x \quad x$

7.0 OCEAN TEMPERATLIRE DIFFERENCES $X \quad X$

8.0 BUILDING HEATING AND COOLING
8.1 Heating
8.2 Cooling
8.3 Hot Water
8.4 Solar Powered Demonstration
8.5 Energy Conservation

$\begin{array}{ll}X & X \\ X & X \\ X & X \\ X & X \\ X & X\end{array}$

9.0 INDUSTRIAL PROCESSING

$X \quad X$




\subsection{HANFORD SITE INFORMATION}

\subsection{General}

The Hanford reservation is located in southeastern Washington at approximately $46-1 / 2^{\circ}$ north latitude. It covers an area of approximately 600 square miles.

The general public has been partially excluded from this area for thirty years. The utilization of vast portions of the area for solar energy collection is thus likely to be met with a minimum of public concern.

The average solar energy falling on the Hanford reservation is approximately $474 \mathrm{MW}$ per square mile. (2) This considers the low energy periods of night time, winter time, and cloudy days. In the summer time when the sun is shining, the energy on a tilted collector is in the $3000 \mathrm{MW}$ per square mile range. Thus at a $33 \%$ efficiency, there is energy in a square mile comparable to the energy produced by McNary Dam. While the average energy in the Hanford area is about the same as the average solar energy throughout the U.S., Hanford has an advantage in the form of amny continuously clear days in the summer time and peak energies similar to those found in areas such as Arizona and New Mexico.

As a solar energy development site, Hanford can be competitive with a majority of the organizations currently deeply involved with solar energy research and development. In fact, the leading solar energy R\&D organizations include northern latitude locations such as the University of Minnesota, University of Wisconsin, University of Pennsylvania, University of Massachusetts, M.I.T., Boston College, University of Delaware, Case Western Research University in Cleveland, and Rutgers of New Jersey. One of the largest programs in the U.S. today for the development of central station solar energy plants is at the University of Minnesota. 
The availability of water from the columbia River is likely to be a plus for any energy production system.

Hanford has an excellent capability for the growing of forest and other plant life which might be applicable to solar energy utilization.

Hanford has the large power system engineering capability and electrical facilities to provide immediate research and development work in central station development.

An application of solar energy which is being studied on a modest scale in the U.S. today is the utilization of ocean temperature differences. There are large basins in the Hanford 100 Areas which conceivably could be used for stationary test beds for systems utilizing water temperature differences. Whether this would provide advantages over actual ocean testing is not known at present.

In summary, it can be said in general that the Hanford site has:

1. An excellent test site for solar energy systems.

2. The physical plant to do development work in almost any area of solar energy.

3. The technical and administrative talent to man solar energy $R \& D$ programs on a small or enormous scale.

\subsection{Climatology}

In July, the mean daily solar radiation on a horizontal surface is greater at Prosser, Wash. (707 Langleys) (3) than at Phoenix (658 Langleys). See Figure 1. Prosser is one of the U.S. weather stations close to the Hanford reservation. The mean daily solar radiation on an annual basis is 520 Langleys 


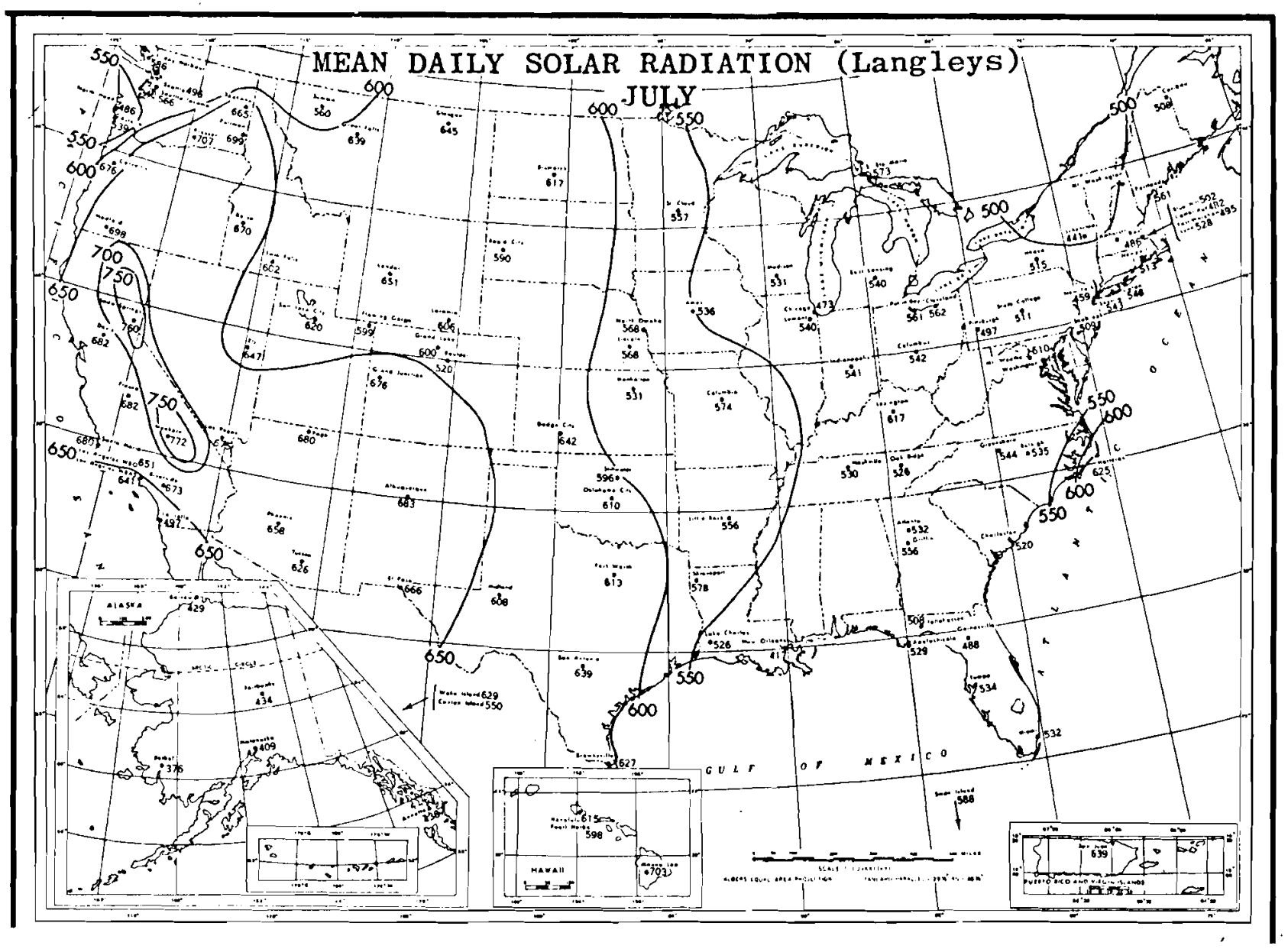

Figure 1

(3)

Mean Daily Solar Radiation (Langleys), July*

* Based on all usuable solar radiation data, direct and diffuse, measured on a horizontal surface and published in the Monthly Weather Review and Climatological Data National Summary through 1962. All data were measured in, or were reduced to, the International Scale of Pyrheliometry, 1956. Langley is the unit used to denote one gram calorie per square centimeter ( 1 langley = $1 \mathrm{gm}$. cal. $\mathrm{cm}^{-2}$. 
at Phoenix and 399 at Prosser, a difference of only $23 \%$.

The average daily total at the Hanford Meteorology Station (2) is 663 Langleys and the yearly average is 372 Langleys. This is slightly lower than at Prosser. It is possible that there is a slight difference in measuring systems.

From Figures $1 \& 2$, Table 2, and References 2 and 3 , the mean daily solar radiation on an annual basis and in July at several locations is shown below.

$\begin{array}{lcr} & \text { Annual } & \text { July } \\ \text { Hanford Met. Station } & 372 & 663 \\ \text { Prosser } & 399 & 707 \\ \text { Los Angeles } & 436 & 651 \\ \text { Washington, D.C. (C.O.) } & 356 & 536 \\ \text { Twin Falls, Idaho } & 378 & 602 \\ \text { Chicago, Ill } & 273 & 473 \\ \text { Lemont, Ill } & 352 & 540 \\ \text { Alberqueque } & 512 & 683 \\ \text { Phoenix } & 520 & 658 \\ \text { Oak Ridge } & 364 & 526 \\ \text { New York } & 298 & 459\end{array}$

As seen in Figure 3 and Table 3, the Hanford reservation is in an area with many total hours of sunshine compared to the rest of the Northwest. The hours of sunshine are comparable to those in Florida, but not comparable to those in the southwest.

In the Hanford area the four cloudiest months are November through February. (2) The remainder of the year, particularly July (see Figure 4) has a high percentage of sunny days.

It should be noted that the energy collected on a given area of properly tilted flat plate or parabolic collector will be only slightly less at $45^{\circ} \mathrm{N}$ latitude than at $20^{\circ} \mathrm{N}$ latitude given comparable atmospheric conditions. This effect is illustrated in Figure 5. The significant fact in this is that while a greater land area may be required in northern latitudes, the collector area is not much greater to collect comparable solar energy while the sun is shining. 




Figure 2. (3) Mean Daily Solar Radiation (Langleys), Annual*

* Based on all usuable solar radiation data, direct and diffuse, measured on a horizontal surface and published in the Monthly Westher Review and Climatological Data National Summary through 1962. A11 data were measured in, or were reduced to, the International Scale of Pyrheliometry 1956. Langley is the unit used to denote one gram calorie per square centimeter (1 langley $\left.=1 \mathrm{gm} . \mathrm{cal} . \mathrm{cm}^{-2}\right)$. 
Table $2^{(3)}$

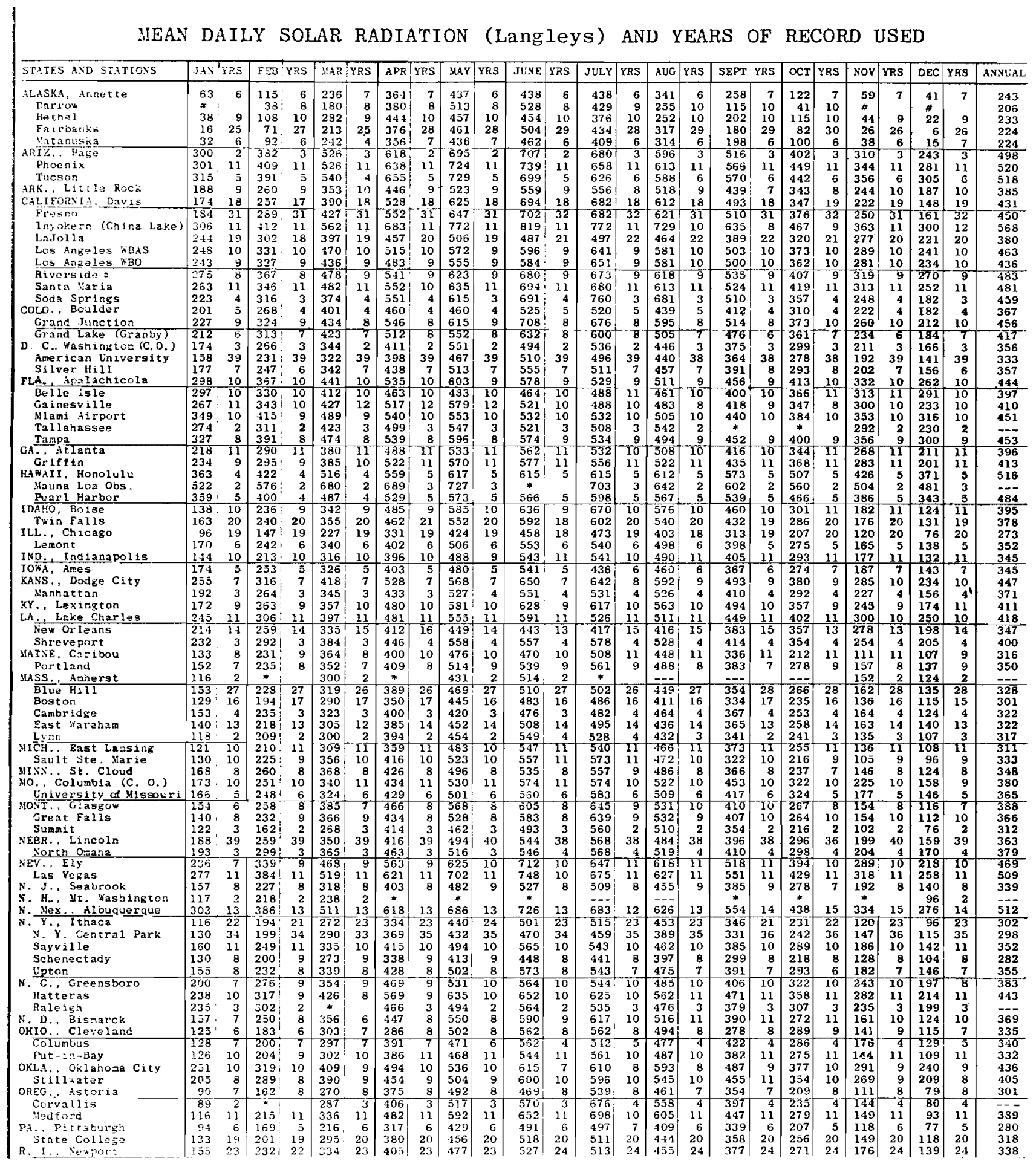


Table 2 (Cont'd)

YIEAN DAILY SOLAR RADTATTON (Langleys) AND YEARS OF RECORD USED

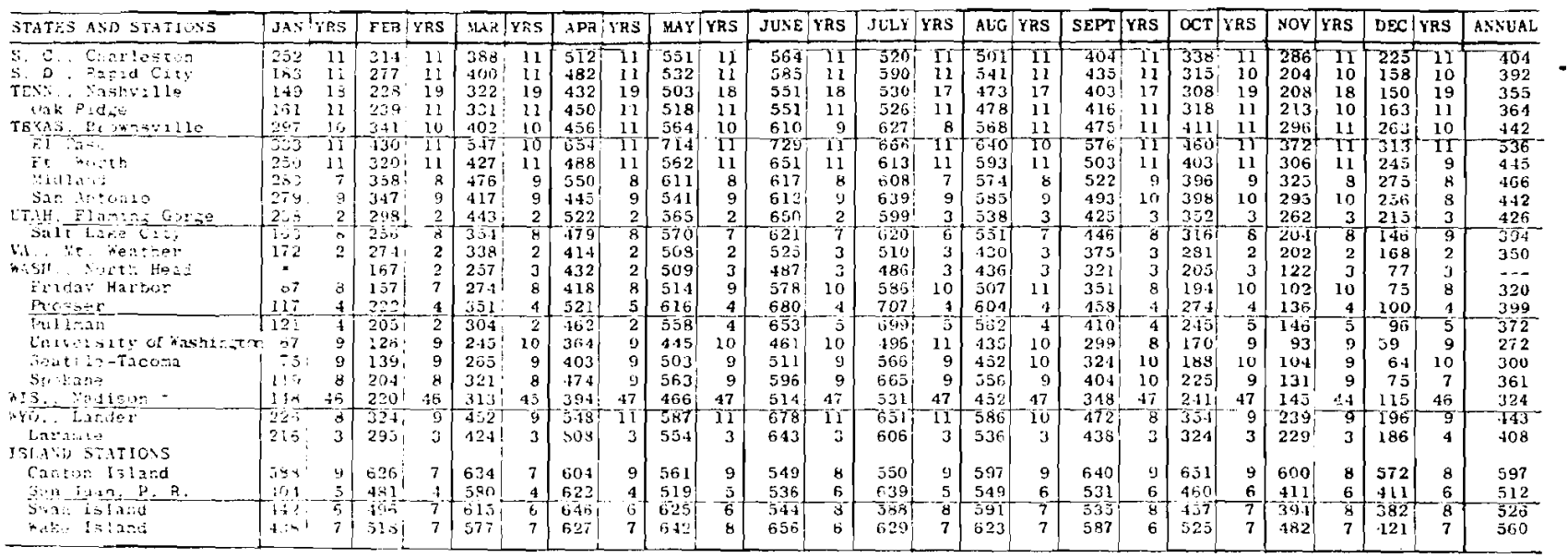

NOTES:

* Wenotes only one year of data for the month -- no mans computed

- No data for the month (or incomplete data for the year)

- Barrow is in darkness during the winter months.

Tiverside data priosto Harch los 2 no exposure influences.

Lanjey is the unit used to denote one gram calorie per square centimeter. 


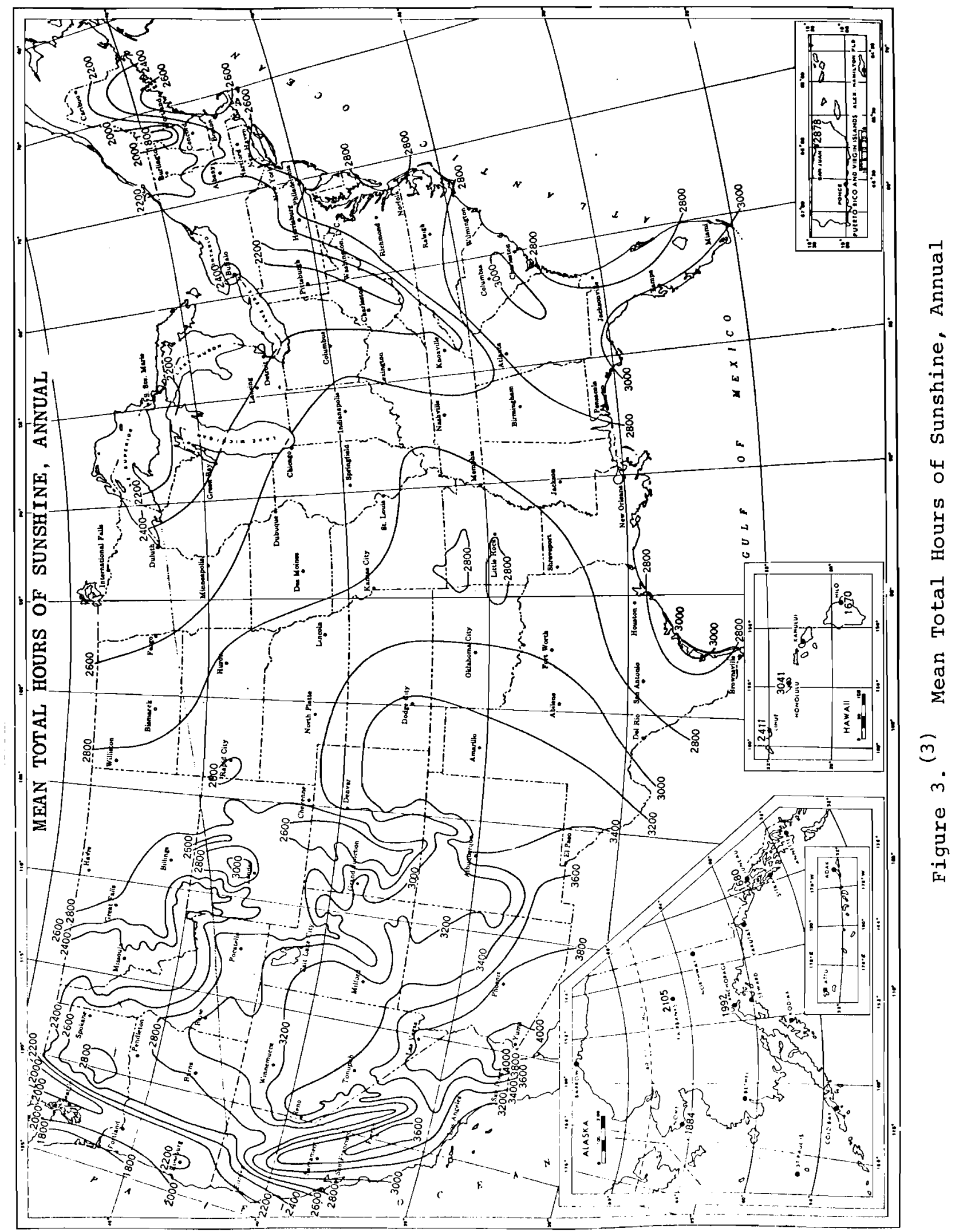




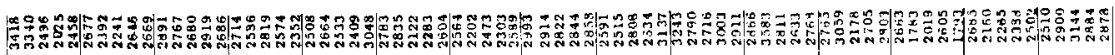
Gw

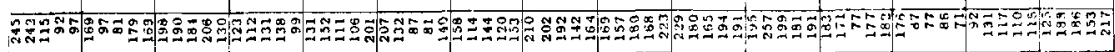
7.



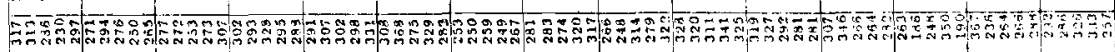
3

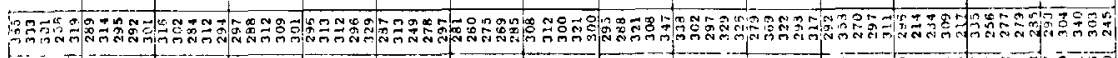

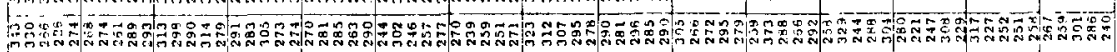

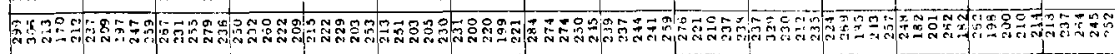

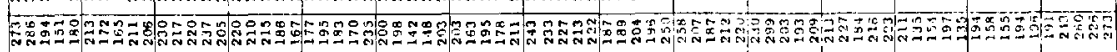

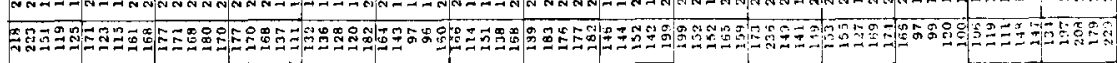

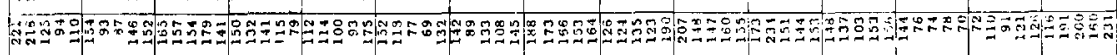
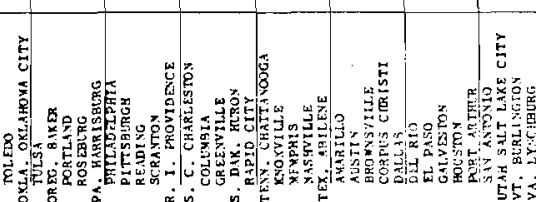

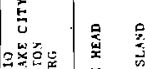

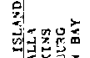


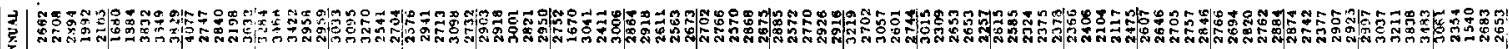

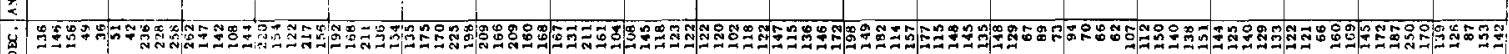

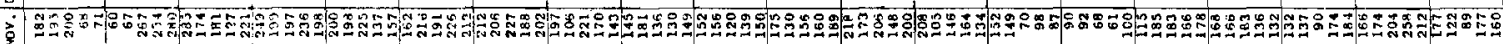
8

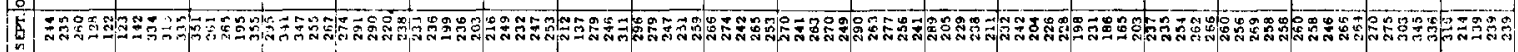

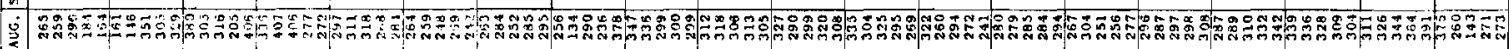

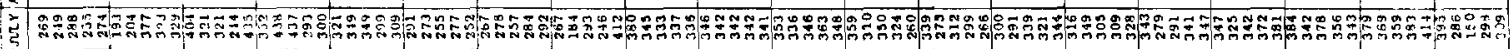

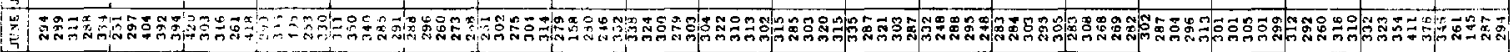

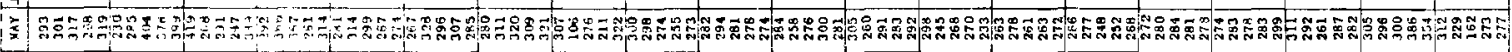
W 5. |

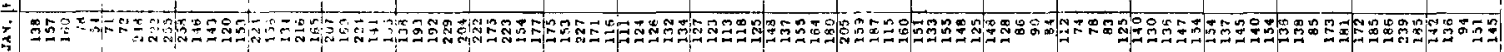
龍






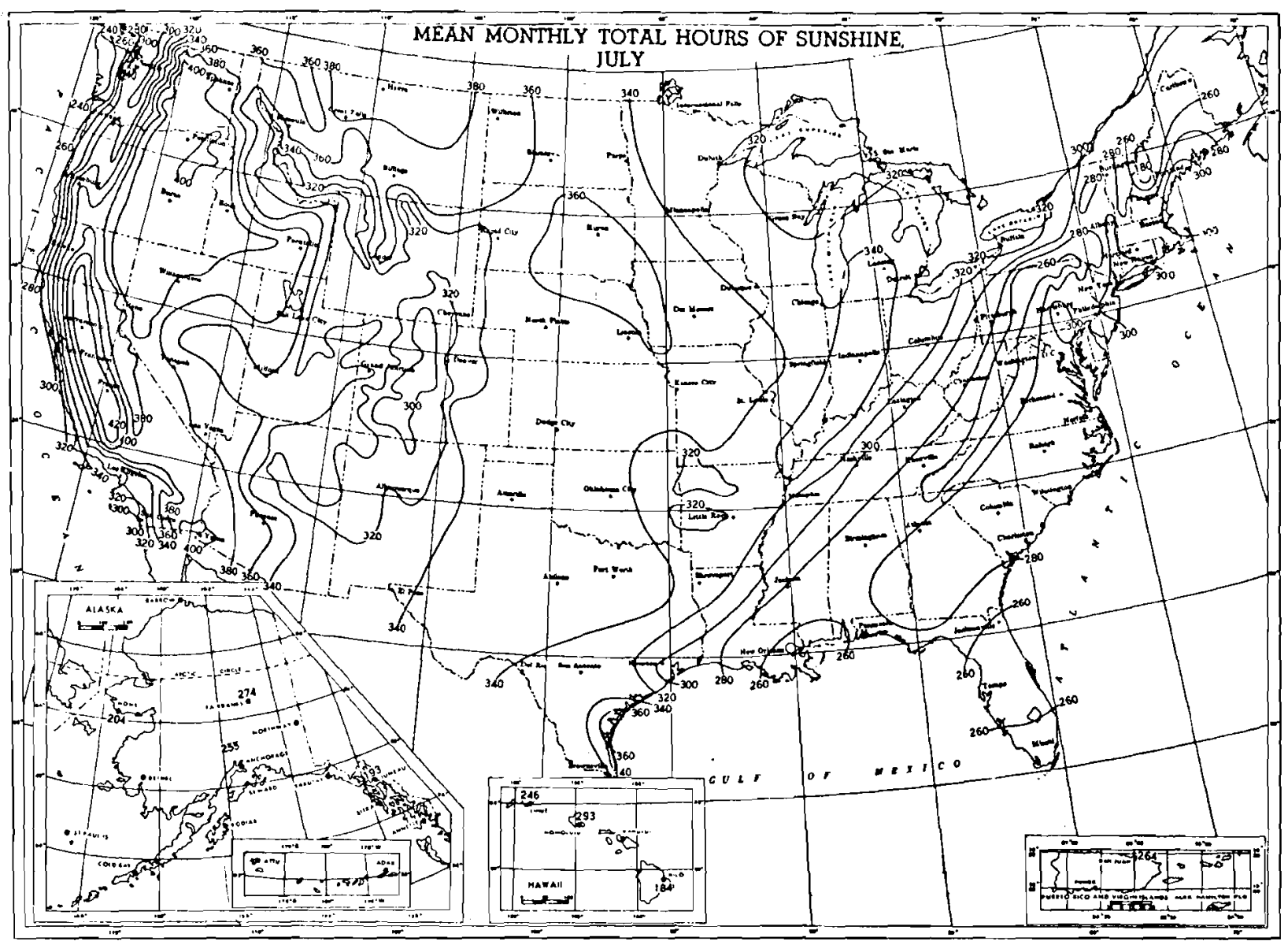

Figure $4^{(3)}$

Mean Monthly Total Hours of Sunshine, July 


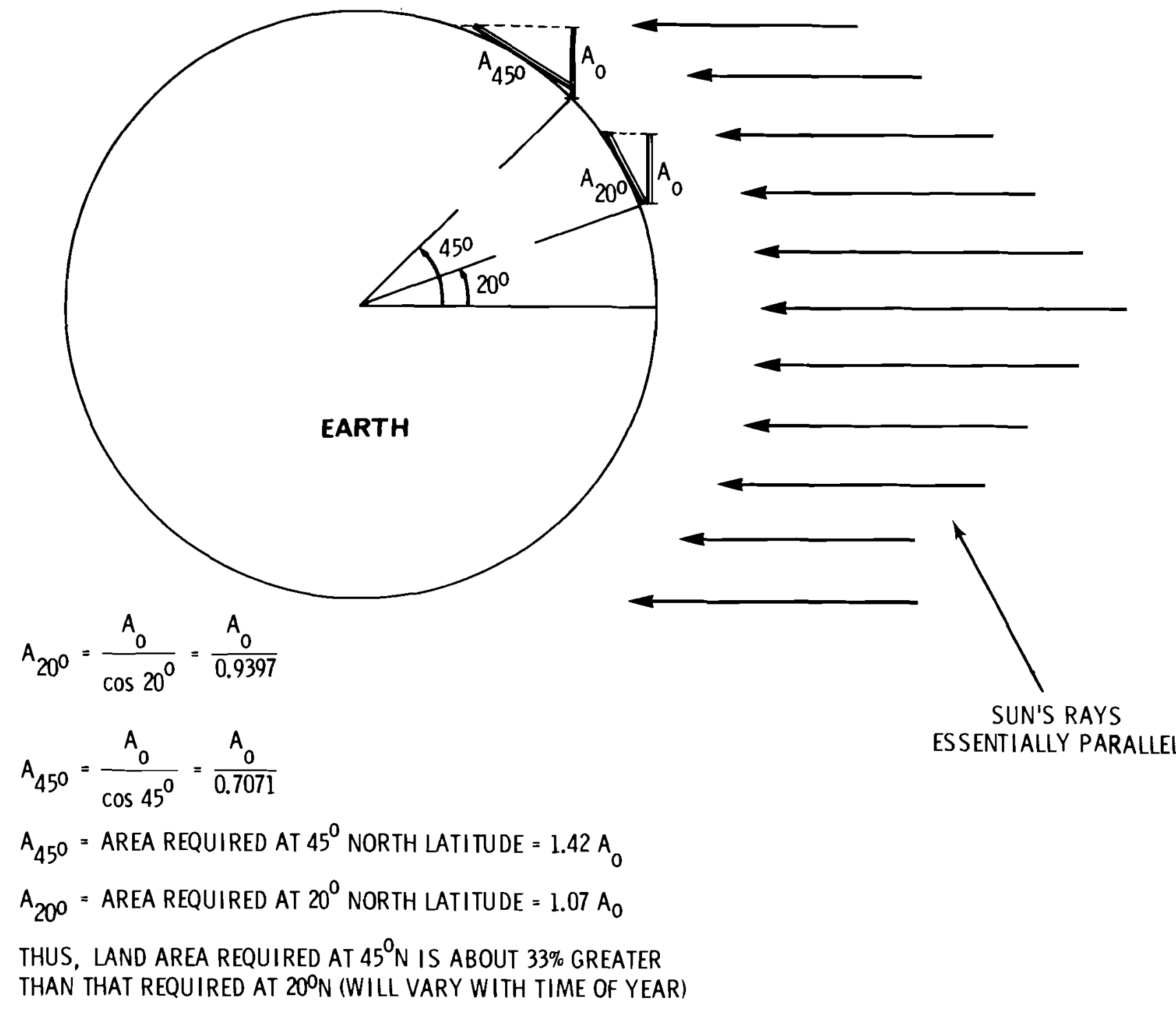

Figure 5. Illustration of the Difference in Solar Energy on Horizontal and Tilted collectors 


\subsection{IMMEDIATE PROGRAM POSSIBILITIES}

There are several programs which could be undertaken immediately to begin to take advantage of the Hanford site. These include:

1. Process development for photovoltaic device fabrication.

2. Process development for thin film heat trap fabrication.

3. Laboratories for collecting, analyzing and disseminating solar insolation data, and for device testing and calibration.

4. Utilization of 100 Area emergency generators for power production.

5. Hydrogen production development.

6. Building heating and cooling system development.

7. Systems analysis and economics.

8. System design.

9. National program planning.

4.1 Process Development for Photovoltaic Device Fabrication Hanford is a leader in thin film fabrication by several different methods. The fabrication of solar cells is likely to utilize thin film processes.

The cost of the basic material in solar cells presently utilized is less than $\$ .05 / \mathrm{sq} . \mathrm{ft}$. The cost of solar cells to be economically competitive with other means of central station power generation is in the $\$ 1 /$ sq.ft. range. The basic requirement for direct solar energy conversion is thus the development of economical fabrication processes. 
Pacific Northwest Laboratory is a leader in the field of sputtered material and has utilized the process for several advanced materials development programs.

The vacuum vapor deposition process developed for periscope mirrors is also potentially applicable to photovoltaic device fabrication. Chemical vapor deposition and thermal decomposition processes developed for isotopic heat source fabrication are also potentially applicable to solar cell fabrication.

Hanford personnel have a background in the fabrication of advanced ceramic and composite materials. This background would be useful in fabrication process development for single crystal solar cells such as the conventional silicon cells.

A broad background in advanced materials fabrication development and volume production processes can bring to bear an unexcelled capability in photovoltaic device fabrication process development.

\subsection{Process Development for Thin Film Heat Trap Fabrication}

The thin film process development capability described above is also directly applicable to the fabrication of interference films which will allow sunlight in through a cover plate but will not allow infrared rays back out. Such films are desirable for solar energy systems which utilize thermal energy. Thermal energy will be used for building heating and cooling, industrial processing, hydrogen production and central station power generation.

This technology is also applicable to the fabrication of reflector surfaces which will retain their reflectivity after long exposure to atmospheric conditions.

The extensive Hanford work in compatibility of materials under long term and elevated temperature conditions will also be directly applicable to heat trap development work. 
4.3 Laboratories for Collecting, Analyzing and Disseminating Solar Insolation Data, and for Device Testing and Calibration(4)

Solar insolation data is incomplete, not standardized, lacks spectral information, suffers from lack of a systematic distribution method, and, in general, is inadequate for the country's present needs. For example, there has not been enough statistical analysis of temporal variation of insolation to permit reasonable evaluation of particular sites. Improvement is needed in intercalibration of devices, and satellite data often suffers from lack of absolute intensity calibration.

National laboratories for collecting, analyzing and disseminating data, and for device testing, calibration, and development are necessary to the orderly development of solar energy systems.

This work is very close to the kind of photometric calibration problems dealt with at Hanford. In fact, a Pacific Northwest Laboratory staff member prepared the standard documentation on photometric calibration for the Bureau of Standards for use during the International Geophysical Year.

\section{4 Utilization of 100 Area Emergency Generators for Power Production}

Several emergency generators are currently installed in the 100 Areas. These emergency generators are designed for operation on steam and are connected to the Bonneville grid.

In the $K$ Areas there are six turbine-generators of $3500 \mathrm{Kw}$ capacity each. They operate on $400 \mathrm{psi}-750^{\circ} \mathrm{F}$ steam. In $\mathrm{B}$ and D Areas there are smaller turbine-generators (750 Kw) which operate at $200 \mathrm{psi}$ with $62^{\circ}$ superheat.

Each of the generator systems has a large (several million gallon capacity) clear well system nearby. The clear wells could quite possibly be utilized as salt tanks for energy storage. With the exception of collectors, basic components are thus in place for electrical generation utilizing solar energy 
steam. These generators are also close to large open areas in which solar collectors could be installed. Solar energy input to the nation's power system could thus be provided with a minimum of engineering and construction work.

For an eight hour day, the average solar energy at Hanford during June, July, and August is about 60 Langleys (calories/ $\mathrm{cm}^{2}$ ) per hour. (2)

Sixty Langleys per hour is equal to 1820 megawatts per square mile. The instantaneous area requirement for 1 megawatt at 60 Langleys/hour is thus

$$
\frac{5280 \times 5280}{1820}=15,200 \mathrm{sq} . \mathrm{ft} .
$$

or an area 123 feet on a side. With a 50\% collection efficiency and 25 응 thermal efficiency, this would be increased to $\frac{15,200}{0.5 \times .25}=121,000 \mathrm{sq} . \mathrm{ft}$, , or an area 347 feet on a side.

At a collector cost of $\$ 10.00$ per square foot, cost of collectors for a one megawatt system would be $\$ 1,210,000$. Low temperature collectors currently sell for $\$ 6.25$ per square foot or less. A collection cost of $\$ 2.00$ a square foot is considered to be within reason. The $\$ 10.00$ per square foot allowance would provide some extra for concentration and headers. It would not provide much for development. However, it is of interest to note that the cost scale for a solar energy demonstration with existing units could be in the $\$ 1,000,000$ per megawatt or $\$ 1,000$ per kilowatt range.

Whether one of the emergency generators for solar energy would be practical is an economics question which can be answered only through detailed analysis. It is technically possible to produce solar electricity in the megawatt range in the immediate future utilizing Hanford emergency generators.

\subsection{Hydrogen Production Development}

The Hanford area has many of the requisites for the development of a hydrogen economy. The production and utilization of hydrogen as an energy source is increasingly being recognized 
as having great potential. Hanford is in an excellent position to participate in hydrogen economy activity.

Hydrogen can be produced with electrical energy, thermal energy, light energy, and biological conversion. The only two systems of significance today are electrolysis utilizing electrical energy and the utilization of hydrocarbons and thermal energy .

Development work is underway on a modest scale at several sites in the world to develop means of producing hydrogen directly from water with thermal energy without using a hydrocarbon.

If the thermal energy systems are successful, then hydrogen can be produced from water through the utilization of thermal energy from reactors, solar energy or geothermal energy as well as fossil energy.

Hydrogen, if it were economical and abundantly available, could be used to meet nearly all of the energy needs of the U.S. It can be used with relatively minor modification to burners or as hydrogen bearing compounds in most systems which use fossil fuels today. For long distance transmission, it can be less expensive to transport energy in the form of hydrogen than in the form of electricity. Existing natural gas pipe lines and systems can be utilized with hydrogen. Hydrogen has the potential for providing economical storage of peak electrical capacity and solar energy.

Hydrogen can also be utilized to increase the effectiveness of fossil fuels in processes such as coal gasification and shale oil extraction.

Hanford facilities and talent can be utilized in the development of hydrogen systems. Hanford personnel have capability in chemical processing, nuclear heat production, geothermal energy utilization and solar energy utilization. 


\subsection{Building Heating and Cooling System Development}

The extremes of temperature in the Hanford areas $\left(-27^{\circ} \mathrm{F}\right.$ to $+1150 \mathrm{~F})$ provide a unique test bed for building heating and cooling systems. Building heating and cooling is planned as one of the first approaches to the utilization of solar power in the U.S. The capability in equipment development, materials development, fabrication process development and construction techniques which exists at the Hanford site could be utilized to provide one of the earliest major programs in building heating and cooling development.

\subsection{Systems Analysis and Economics}

Hanford personnel have for years led in establishing the economic position of various energy producing systems. This expertise is directly applicable to optimizing the utilization of solar energy in the U.S.

In addition to establishing the position of solar energy systems in the overall energy picture, Hanford expertise can be utilized in the economic development of solar energy systems. The choice of economical alternate paths for development is essential to sound engineering.

\subsection{System Design}

Hanford expertise in the development and design of large reactor systems is directly applicable to the design of central station solar power systems.

\subsection{National Program Planning}

Hanford personnel have participated in the development of national program plans on a large scale for several energy systems.

One of the fundamental needs for an expanded national solar energy program is the definition of a research and development program in terms of problems to be solved, dollars necessary to solve the problems, and time. Hanford personnel have 
a unique capability in defining large scale R\&D programs.

\subsection{Other}

It is almost a certainty that as a more aggressive national solar program develops, additional possibilities for immediate programs will be recognized. 


\subsection{SOLAR ENERGY SPONSORS}

\subsection{Government}

The principal government sponsor of solar energy work is the National Science Foundation. Work sponsored by them in FY 1973 is summarized in Appendix A. Their present FY 1974 budget is \$12-14 M. However, a program plan has been prepared which calls for substantially greater expenditures.

The recently announced reorganization of the AEC may have a significant effect on the AEC position with respect to solar energy.

The Department of Commerce has an interest in solar power and has funded some work in the past. They may fund small projects directed towards Department of Commerce goals.

The Department of Housing and Urban Development has an interest in solar power and could possibly sponsor significant projects relating to building heating and cooling.

The Post office Department reportedly has funded a $\$ 1$ million program at the University of Pennsylvania on the solar heating and cooling of post office buildings.

The Department of the Interior has general energy money in FY 1974. Some of this could be applied to solar power work, particularly in the area of coal gasification or shale oil production.

NASA has funded some solar energy work in the past, generally directed at space projects. The utilization of solar power for terrestrial purposes has become a primary NASA goal. NASA laboratories, faced with cutbacks in the space programs, have developed sizable solar power programs (as yet largely unfunded). However, because of the cutbacks, they will probably support in-house work to the maximum possible extent. 
It is expected that the responsibilities discussed above will become more orderly in the near future and that more specifically defined responsibilities will be established.

The NSF-NASA panel recommended in their report to the OST that the National Solar Power program be increased to $\$ 3.5$ billion over the next 15 years or over $\$ 200$ million per year. There are thus growing indications that solar power funding will increase significantly in the very near future.

\subsection{Industrial Sponsors}

Utilities have provided group sponsorship for solar power programs in the past. A group of southwest utilities sponsored the Meinels at the University of Arizona in 1972. Utilities, along with the state of Delaware, have funded a substantial program at the University of Delaware.

The EPRI goals document indicates $\$ 168$ million for solar power over the next 29 years. It is expected that their interest may increase since the estimate was prepared before solar power became popular.

Particularly in the area of coal gasification or shale oil extraction, energy companies could be potential sponsors. However, it should be recognized that they generally have in-house capability.

There are small hot water heater companies in Florida. None of these have grown to significant size as yet. However, any manufacturer of equipment, such as air conditioners or furnaces, can be considered as a potential sponsor. 


\section{REFERENCES}

1. An Assessment of Solar Energy as a National Resource, by NSF-NASA Solar Energy Panel, Dr. Paul Donovan, et. al, December, 1972 .

2. Climatography of the Hanford Area, BNWL-1605, W. A. Stone, et. al, June 1972 .

3. Climatic AtZas of the United States, U. S. Department of Commerce, Environmental Science Services Administration, Environmental Data Service, Woodrow C. Jacobs, Director, June, 1968, U. S. Government Printing Office, $1968,0-311-220$.

4. Letter, R. J. Hock, BNW, November 13, 1973. 


\section{A P PE $\| D I X \quad A$}

SOLAR ENERGY BACKGROUND 
APPENDIX A

SOLAR ENERGY BACKGROUND

\subsection{Basic Systems}

There are several basically different systems for the utilization of solar energy. These include thermal conversion which may utilize concentrated sunlight to make steam, direct conversion such as photovoltaics, chemical conversion, photosynthesis, biological conversion, and industrial processing. Thermal systems also include the utilization of ocean temperature differences.

One of the keys to the effective utilization of thermal systems is the development of cheap interference films which will allow the sun's energy to pass through but will not let infrared rays back out. These heat traps are available to a degree. However, there is much room for improvement and cost reduction.

There are two schools of thought on the best geographical method of utilizing solar energy. One favors central station systems and the other localized systems. An example of the latter is the utilization of the roof area of a building for heating, cooling and power.

Industrial processing is an area of potential in which little has been done to date.

\subsection{Thermal Conversion}

Thermal conversion systems generally utilize mirrors or Fresnel lenses to concentrate sun on a boiler or primary coolant fluid. A solar collector for a thermal system is illustrated in Figure 1. 


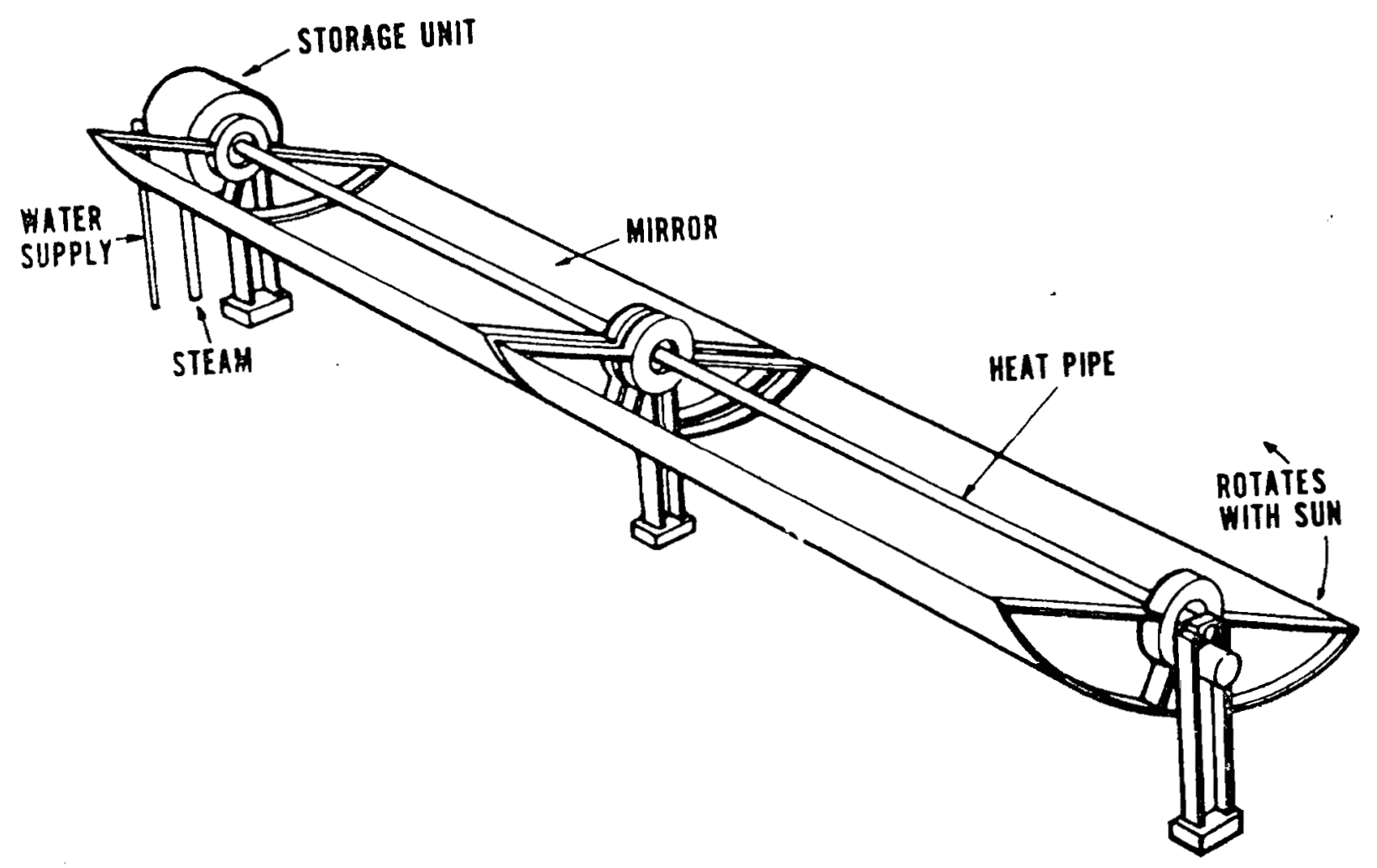

Figure 1. Solar Collector Concept (1) 
Francia in Italy built small plants beginning in the early 1960s. (2) These plants operate at temperatures up to $600^{\circ} \mathrm{C}$ and achieve insolation-to-heat-input efficiencies of $70 \%$.

Meinel of the University of Arizona contributed greatly to the present increase in solar power interest by publicizing

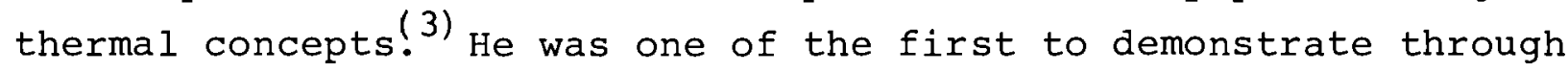
calculations that the economics for large scale thermal plants were promising.

Another study of thermal plants is currently underway by the University of Minnesota and Honeywell. (1) This is the most complete thermal program in progress. The University of Minnesota expects to start a pilot plant within the next two years. They are working with Babcock and Wilcox as well as Honeywell. (4)

Generally speaking, thermal plants are felt to be a factor of 5 or so too expensive to build right now. Improvements in materials, tracking systems and engineering are required for them to be competitive.

Storage methods considered for thermal systems include heat storage in rocks or salt, pumped storage of water or air, chemical storage, storage in geological formations such as salt flats, geothermal caverns, etc.

\subsection{Direct Conversion}

The most commonly considered systems for direct conversion are photovoltaic devices such as silicon or cadmium sulfide cells.

Silicon cells are considered expensive and there are those who feel they can never be economically practical. They are currently made by growing single crystals of silicon, cutting up the single crystal (with a material loss of up to $80 \%$ ) and doping with trace elements. There is some potential for the 
achievement of columnar grain structures with thin film deposition processes. This could greatly reduce the cost. There are some concepts in silicon cell technology which, if successful, could make them economically competitive.

Silicon cells are relatively efficient photovoltaic devices with a conversion efficiency of 10 to $20 \%$. Ten percent efficiency is considered good with $20 \%$ being at the top of the theoretical range. (6)

Cadmium sulfide cells have the potential for much less expensive fabrication. They can be made by simply coating a substrate with a few microns thick layer of cadmium sulfide. The principal problem in producing cadmium sulfide cells is reproducibility. The efficiency of present day cells is in the 5\% range.

There is some possibility that solar cells can be used with a concentration factor of 10 or so which would reduce the number of solar cells required accordingly.

Organic solar cells are not available at this time, and there is little literature on them. There are some who feel that organic semiconductors can some day be made cheaply with overall efficiencies of $80 \%$. (7) The high efficiency would be achieved by using several layers of semiconductors with each layer taking out a part of the spectrum and allowing the rest to be transmitted to the next layer. Conceivably, these materials can be made almost as cheaply as polyethylene plastic.

Thermionic and thermoelectric devices are also considered. However, they are not generally felt to have great potential for solar power because of low efficiencies.

Storage systems considered for direct conversion systems include electrolysis, batteries, and pumped storage of water or air. 


\subsection{Chemical Conversion}

One of the most promising systems for the utilization of solar energy is the thermal dissociation of water. If systems can be developed for this, a virtually inexhaustible supply of clean fuel and a practical storage and transportation system for solar energy will be in hand.

There is also the possibility of applying solar energy to coal gasification, thus achieving the gasification of most of the coal rather than the $50 \%$ that is gasified with most present day processes.

The production of oil from oil shale requires temperatures of only about $700^{\circ} \mathrm{F}$. This is another potential application for solar energy.

There are other potential reactions for thermal energy storage.

\subsection{Photosynthesis}

The photosynthesis of solar energy in plant-life is considered by the National Science Foundation as one of the promising potential systems. It is stated that efficiencies up to $3 \%$ can be achieved in terms of thermal energy.

The conversion of organic matter to fuel is another potential system.

There is a minor amount of work being done on bacteria systems. (8)

\subsection{Industrial Processing}

With improvements in solar concentration systems, solar industrial processing may become practical. Approximately 25\% of our energy today is used for industry. This is an open market for solar power. 


\subsection{Ocean Temperature Differences}

A system which uses the thermal gradients from ocean areas such as the Gulf Stream has some promise. (9) This type of system is illustrated in Figure 2. The temperature difference is used to operate a low vapor pressure turbine. Systems utilizing ocean temperature differences have actually been built and operated. They are not economically practical at present but may be in the future. Three independent engineering analyses indicate the system may be economically feasible today. Some experimental work must be done before it is known whether the potential is really there. For example, heat exchangers which can be economically built and which will stand up in the ocean without scaling or corroding away must be demonstrated.

\subsection{Building Heating and Cooling}

There are many areas of the country in which solar heating would be economical today. This is illustrated in Table 1. However, solar heating systems currently require more attention than conventional systems and generally are more effective when the building is designed for solar heating.

Solar refrigeration systems have been built. To date, these systems have operated on low grade heat and have been relatively inefficient. Commercial solar cooling systems are not yet available.

Commercial solar hot water heaters are available and have been used to some extent in California and Florida. They generally lose popularity as other energy distribution systems become effective. However, because of the high cost of fuel and electricity today, they may once again become popular.

\subsection{Environmental Effects}

Some people are fond of saying that the utilization of solar power would not have any environmental impact because we receive solar power anyway. This is not true. Significant environmental impact can be expected from solar energy utilization, and it is essential that environmental considerations be handled from the beginning. 


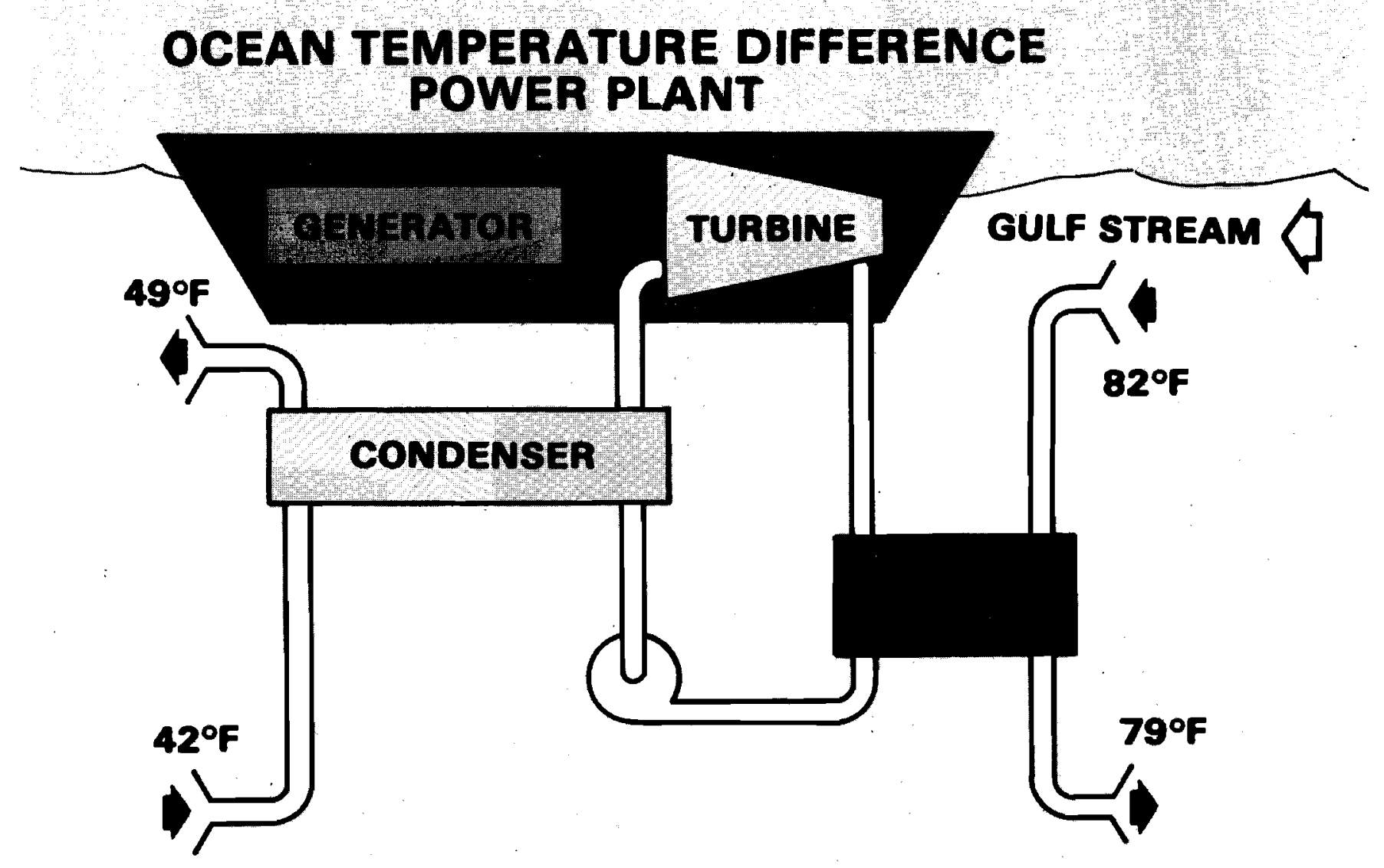




\title{
COSTS OF SPACE HEATING (1970 Prices) IN DOLLARS PER MILLION BTU USEFUL DELIVERY
}

\begin{abstract}
(From "An Assessment of Solar Energy as a National Resource," by NSF-NASA Solar Energy Panel, Dr. Paul Donovan, et. al, Dec. 1972.)
\end{abstract}

\begin{tabular}{|c|c|c|c|c|c|}
\hline \multirow[t]{2}{*}{ Location } & \multicolumn{2}{|c|}{$\begin{array}{c}\text { Optimized solar heating } \\
\text { cost in } 25,000 \text { BTU/degree- } \\
\text { day house, capital charges } \\
@ 6 \%, 20 \text { years }\end{array}$} & \multirow{2}{*}{$\begin{array}{c}\text { Electric } \\
\text { heating, } \\
\text { usage } \\
30,000 \\
\text { kwh/year }\end{array}$} & \multicolumn{2}{|c|}{$\begin{array}{l}\text { Fuel heating, } \\
\text { fuel cost } \\
\text { only }\end{array}$} \\
\hline & $\begin{array}{c}\text { Collector @ } \\
\$ 2 / \mathrm{ft}^{2}\end{array}$ & $\begin{array}{c}\text { Collector @ } \\
\$ 4 / \mathrm{ft}^{2}\end{array}$ & & Gas & Oil \\
\hline Santa Maria & 1.10 & 1.59 & $4.28^{1}$ & 1.52 & 1.91 \\
\hline Albuquerque & 1.60 & 2.32 & 4.63 & 0.95 & 2.44 \\
\hline Phoenix & 2.05 & 3.09 & 5.07 & 0.85 & 1.89 \\
\hline Omaha & 2.45 & 2.98 & $3.25^{3}$ & 1.12 & 1.56 \\
\hline Boston & 2.50 & 3.02 & 5.25 & 1.85 & 2.08 \\
\hline Charleston & 2.55 & 3.56 & 4.22 & 1.03 & 1.83 \\
\hline Seattle-Tacoma & 2.60 & 3.82 & $2.29^{2,3}$ & 1.96 & 2.36 \\
\hline Miami & 4.05 & 4.64 & 4.87 & 3.01 & 2.04 \\
\hline
\end{tabular}

Notes: 'Electric power costs are for Santa Barbara, Electric power data for Santa Maria were not available.

${ }^{2}$ Electric power costs are for Seattle.

'Publicly owned utility.

Solar heat costs are from optimal design systems yielding least cost heat.

Electric power heat costs are from U.S. Federal Power Commission. All Electric Homes, Table 2 (1970). Conventional heat fuel costs are derived from prices per million BTU reported in P. Batestra, The Demand for Natural Gas in the United States, Tables 1.2 and 1.3 (North Holland Publishing Co., 1967). The 1962 costs were updated to 1970 by use of national price indexes on gas (121.1 in 1970 versus 112.8 in 1962 ) and on fuel oil (119.22 in 1970 versus 101.2 in 1962) as adjustment factors on each fuel price in each state. Bureau of Labor Statistics fuel prices indexes obtained from Gas Facts. Fuel prices were converted to fuel costs by dividing by the following national average heat (combustion) efficiencies: gas, 75\%; oil, 75\%. Heat efficiencies are from American Society of Heating. Refrigerating and Air Conditioning Engineers, Guide and Data Book 692-694 (1963 ed.).

All solar heat costs based on amortizing entire solar system capital costs in 20 years at 6 percent interest. Capital investment based on current prices of solar water heaters at $\$ 4$ per sq. $\mathrm{ft}$. plus current costs of other components, and on anticipated near-term solar collector price of $\$ 2$ per sq. $\mathrm{ft}$. 
There is a basic energy balance difference in the utilization of solar power. If solar power is collected, there will be less heat radiating from the point of collection than under normal circumstances. For electrical power generation, this heat would be transferred to another location and probably be reirradiated at a lower temperature and thus at a slower rate. It is unlikely that this would have significant effects on the overall heat balance of the earth. However, it could have localized effects and certainly the earth's heat balance must be considered in the long term. Incidentally, it should be noted that geothermal power probably has an opposite effect in that heat which is normally diffused out of the earth's surface is brought up to the surface where it will radiate at a higher temperature. Conceivably the utilization of geothermal and solar power could be used to balance the earth's heat inventory.

Localized solar power plants will have potential visual impact and local shading effects. For some types of plants there may be a problem in the elimination of waste heat.

For the utilization of ocean temperature differences, the ocean might ultimately be reduced in temperature. This could have the greatest effects in areas such as the Cape cod area which currently benefit from the Gulf stream.

If futuristic concepts such as the space collection of solar energy ever become feasible, the power transmission and collection system could have significant environmental impact.

The forest growing aspects of solar power could prove to have beneficial impact. In this concept, it should be noted that the burning of fuel grown with solar power will increase the $\mathrm{CO}_{2}$ in the atmosphere. However, the forest would deplete $\mathrm{CO}_{2} \cdot$ 
Probably a minimum environmental effect would result from the local use of building roof areas for solar heating and cooling and for energy production for this application. Visual impact will undoubtedly be considered initially. 


\section{REFERENCES}

1. Research Applied to Solar-Thermal Power Systems, NSF/RANN/SE/GI-34871/PR/72/4, by U. of Minn. and Honeywell, January 1973 .

2. G. Francia, Pilot Plants of Solar Steam Generating Stations, Solar Energy, Vol. 12, pp. 51-64, 1968.

3. Meinel, Aden \& Majorie, Is it Time for a New Look at Solar Energy, Bulletin of the Atomic Scientists, October, 1971 .

4. Personal communication, Dr. R. C. Jordan, U. of Minn., April 19,1973.

5. C. G. Currin, et. al, Feasibility of Low Cost Sizicon Solar Cells, Dow Corning Corporation, Hemlock, Michigan.

6. Solar Celzs, Outzook for Improved Efficiency, National Academy of Sciences, 1972.

7. The Future of Power from the Sun, by P. E. Glaser, Power, August 1968 .

8. An Assessment of Solar Energy as a National Resource, by NSF-NASA Solar Energy Panel, Dr. Paul Donovan, et. al, December, 1972 .

9. J. Hilbert Anderson and James H. Anderson, Jr., Large Scale Sea Thermal Power, paper presented to the American Society of Mechanical Engineers, November, 1965. 
APPENDIX B

PROGRAM POSSIBILITIES 


\section{APPENDIX B}

\section{PROGRAM POSSIBILITIES}

\subsection{National Program Outline}

The recent NSF-NASA report outlines a prospective national program. The outline of Table 1 (from page 5 of the main report) includes some additional items. This outline is presented here as a summary of the type of work involved in a reasonably complete solar energy $R \& D$ program. A comparison of Hanford capability with this outline indicates that contributions can be made in almost every area.

\subsection{Comments on Specific Problems Relating to Hanford}

\section{Capabilities}

Specific problems are indicated below. Comments on specific problems are by no means complete. They are intended only to illustrate the existence of a plentiful $R \& D$ field. It should also be noted that thoughts below may be impractical. However, several will warrant a preliminary analysis. The numbers below relate to the outline of Table 1 of the main report.

\subsection{Solar Energy Availability}

The information on solar energy availability in the Hanford area is probably as complete as that for any place in the country. Using this as a starting point, a study of the availability of solar energy in the Northwest as a part of an overall national program to more closely define solar energy availability.

\subsection{Albedo}

A preliminary analysis of the effects of large scale utilization of solar power on the earth's heat balance and area heat balance.

\subsection{Photon Matter Interactions}

Optimal glass for Fresnel lenses and heat traps. Glasses which will transmit a maximum of desirable parts of the spectrum. 
Table 1

SOLAR ENERGY PROGRAM OUTLINE

1. 0 GENERAL

1.1 Solar Energy Availability

1.2 Albedo

1.3 Solar Energy Characteristics

1.4 Photon - Matter Interactions

1.5 Environmental Effects

1.6 Economics

1.6.1 Overall Energy System

1.6.2 Individual Systems

1.6.3 Technical Assistance

1.7 Systems Analysis

2.0 THERMAL CONVERSION

2.1 Collectors

2.1.1 Reflector Materials \& Fab

2.1.2 Corrosion Resistant Materials

2.1.3 Compatibility

2.1.4 Fresnel Lenses

2.1.5 Thin Film Heat Traps

2.1.6 Mass Production Techniques

2.2 Storage

2.2.1 Eutectic Salts

2.2.2 Geothermal Caverns

2.2.3 Other

2.3 Heat Transfer

2.4 Systems

2.5 Pilot Plant

2.6 Demonstration Plant

3.0 DIRECT CONVERSION

3.1 Solid State Studies

3.1.1 General

3.1.2 Silicon Systems

3.1.3 cas systems

3.1 .4 Other Inorganic

3.1 .5 Organic 
Table 1 (Cont'd)

3.0 DIRECT CONVERSION (Cont'd)

3.2 Solar Cell Fabrication

3.2.1 Single Crystal

3.2.2 Polycrystalline

3.2.3 Amorphous

3.2.4 Organics

3.3 Power Collection

3.4 Controls

3.5 Pilot Plant

3.6 Demonstration Plant

4.0 CHEMICAL CONVERSION

4.1 Thermal Dissociation of $\mathrm{H}_{2} \mathrm{O}$

4.2 Hi Temperature Electrolysis

4.3 Combined Thermal-Electrolysis

4.4 Other Chemical Conversion Systems

4.5 Chemical Energy Storage

4.6 Support

5.0 PHOTOSYNTHESIS

5.1 Growing Forests

5.2 Other Photosynthesis

5.3 Conversion of Organic Materials to Fuels or Heat

6 . 0 BIO-CONVERSION

6.1 Photosynthesis Bio-conversion

6.2 Thermal Bio-conversion

6.2 .1 Algae

6.2 .2 Organics

7.0 OCEAN TEMPERATURE DIFFERENCES

8.0 BUILDING HEATING AND COOLING

8.1 Heating

8.2 Cooling

8.3 Hot Water

8.4 Solar Powered Demonstration

8.5 Energy Conservation

9.0 INDUSTRIAL PROCESSING 


\subsection{Environmental Effects}

The ecological evaluation of the effect of shading large areas.

1.6 Economics

1.6.1 Overall Energy System

As a reference work for future analyses relating to

solar power and other energy systems, it is desirable to establish the areas taken by hydro plants, fossil plants, nuclear reactors - including the total operating cycle from mine to waste storage, etc. This should help to put the area required for solar plants in perspective and could also be useful in other analyses.

The development of standard codes for solar energy economic comparisons.

A study of the requirements in our society for the acceptance of solar heating and cooling in homes.

A study of the financial requirements, such as including solar heating in home mortgages, to achieve utilization of solar power.

An analysis of the potential application of solar power to a variety of home utensils.

Some assistance could be given indirectly in the development of a national plan for solar energy development.

\subsubsection{Reflector Materials and Fab}

The development of a cheap process for reflector fabrication.

\subsubsection{Corrosion Resistant Materials}

The development of reflective materials which have the potential to last for 20 years. 


\subsubsection{Fresnel Lenses}

The development of cheap processes for the fabrication of glass fresnel lenses, such as extruding or pressing long panels.

\subsubsection{Thin Film Heat Traps}

The development of cheap processes for the fabrication of interference films.

\subsubsection{Geothermal Caverns}

The utilization of geothermal-solar systems to provide 6 month-type energy storage.

\subsection{Heat Transfer}

The development of heat pipes for solar energy systems.

\subsection{Pilot Plant}

The design and construction of a pilot plant utilizing existing 100 Area emergency generators. This could provide the first solar power in-put to us power grids.

\subsection{Solid State studies \\ 3.1 .2 Silicon Systems}

The photovoltaic properties of silicon structures with columnar grains.

\subsubsection{Cadmium Sulfide Systems}

Basic properties necessary for cheap production techniques for cadmium sulfide systems.

\subsubsection{Organic}

Determination of the properties of organic semiconductors.

\subsubsection{Single Crystal}

The growth of shaped and segmented silicon single crystals. 
Some years ago there was very preliminary work done on the growth of aluminum oxide single crystals in the shape of a dog bone. By jolting the molten $\mathrm{Al}_{2} \mathrm{O}_{3}$ ultrasonically as the crystal was pulled from the melt, an impurity buildup was achieved intermittently along the crystals. The single crystal was shaped magnetically to a dog-bone cross-section. Theoretically, the crystals could be tapped with a hammer and shattered to numerous individual sapphires with a built-in dog bone shape. This was done as a part of the composite materials program. Conceivably, it would provide a very inexpensive way of making silicon semiconductors.

\subsubsection{Polycrystalline}

Work for NASA in tungsten coating some years ago developed a technology for producing columnar grains of tungsten in thin films. Similar techniques conceivably could produce single crystal columnar grains of silicon to achieve photovoltaic effects.

\section{2 .3 Amorphous}

Development of cheap processes for the fabrication of photovoltaics such as cadmium sulfide.

\section{$3.3 \& 3.4$ Power Collection and Control}

The development of energy collection and control systems for large scale photovoltaic systems. The output of a solar cell is in the one volt range. The utilization of solar energy in a photovoltaic system in a central station power will require the attachment of thousands of solar cells and the collection of the energy from these cells in a manner which will minimize energy losses and permit inexpensive maintenance operations. There seems to have been little conceptual design in methods which would actually function. Preliminary design work at this point can point out some of the future problems of the photovoltaic systems. 
4.1 Thermal Dissociation of $\mathrm{H}_{2}$ O

The development of systems for the thermal conversion of water to hydrogen and oxygen.

\subsection{Combined Thermal-Electrolysis}

A dissociation system which combines the thermal combination of primary chemicals with regeneration by electrolysis.

\subsection{Other Chemical Conversion Systems}

The dissociation of chemicals other than $\mathrm{H}_{2} \mathrm{O}$ for recombination to achieve energy extraction. A study of alternates to hydrogen and oxygen for chemical energy storage systems.

The aevelopment of processes for shale oil extraction.

The development of processes for the utilization of solar energy for coal gasification.

\subsection{Chemical Energy Storage}

The development of systems for hydrogen storage.

\subsection{Support}

Evaluation of materials which might be utilized in chemical storage systems such as hydrogen production.

\subsection{Ocean Temperature Differences}

Utilization of the large basin in the 100 Areas to test ocean temperature differences systems. One basin could be filled with water at $42^{\circ}$ and the adjoining basin with water heated by solar power to $80^{\circ}$ to provide a controlled test bed for ocean temperature differences systems. 
8.1 Heating

The development of cheap, reliable and easily operable systems for building heating.

8.2 Cooling

Cheap reliable and easily operable systems for building cooling.

8.3 Hot Water

Cheap reliable and easily operable systems for building hot water.

\subsection{Solar Powered Demonstration}

It was suggested some time ago that a building powered completely by solar power would be a good demonstration and test bed. This subject has been mentioned many times since and almost invariably the reaction is that it really sounds good.

\subsection{Industrial Processing}

A survey of processes which might effectively utilize solar heat (temperature - heat - capital cost).

The design and construction of a solar heating system for general chemical processing uses.

The application of solar power to the production of cement from limestone.

The application of solar power to agricultural processing. 
A P PENDIX C

FY 1973 SOLAR ENERGY PROGRAMS

SPONSORED BY IISF 


\section{$\mathrm{C}-1$ \\ APPENDIX C \\ FY 1973 SOLAR ENERGY PROGRAMS SPONSORED BY NSF}

Studies of Thermal Conversion of Solar Energy for Electrical Power Production, Aden B. Meinel, University of Arizona, Tucson, Arizona 85721, \$107,000.

Low-Cost Silicon Photovoltaic Cells for Large Solar Power systems, P. H. Fang, Boston College, Chestnut Hill, Massachusetts, $\$ 52,200$.

Direct Solar Energy Conversion for Large Scale Terrestrial Use, Karl W. Boer, University of Delaware, Newark, Delaware 19711, $\$ 291,200$.

Hydrogen Production by Photosynthesis and Hydrogenase Activity-and Energy Source, L. O. Krampitz, Case Western Reserve University, Cleveland, Ohio $44106, \$ 150,000$.

Solar Energy Panel, Frederick H. Morse, University of Maryland, College Park, Maryland 20742, \$57,800.

Ocean Sited Power Plants, William E. Heronemus, University of Massachusetts, Amherst, Massachusetts 01002, \$145,100.

Research Applied to Solar-Thermal Power Systems, R. C. Jordan, University of Minnesota, Minneapolis, Minnesota, $\$ 446,600$

Technology for the Conversion of Solar Energy to Fuel Gas, Iraj Zandi, University of Pennsylvania, Philadelphia, Pennsylvania, $\$ 195,000$.

An Improved Schottky Barrier Photovoltaic Diode for Solar Energy Conversion, Wayne A. Anderson, Rutgers, The State University, New Brunswick, New Jersey, 08903, \$16,000.

Computer Modeling and Simulation of Solar Heating and Cooling Systems, W. A. Beckman, University of Wisconsin, Madison, Wisconsin, 53706, \$75,000.

A Proposal in Response to NSF RFP 72-121, A. B. Greenberg, Aerospace Corporation, El Segundo, California, $\$ 125,000$.

Thermal Conversion of Solar Energy for Electrical Power Production, Aden B. Meinel, University of Arizona, Tucson, Arizona, $\$ 64,400$.

Conservation and Better Utilization of Electric Power, Manfred Altman, University of Pennsylvania, Philadelphia, Pa. 19104, $\$ 530,000 ;$ Synthetic-Solar Fuel Cycle, $\$ 600,000$. 